\title{
PERFORMANCE COMPARISON OF ISLAMIC BANKS AND CONVENTIONAL BANKS IN PAKISTAN
}

\author{
Rabeea Rizwan \\ BS (Accounting \& Finance), IBA Karachi, Pakistan \\ E-mail: rabeearizwan8@gmail.com
}

\begin{abstract}
The objective of this paper is to compare and analyze the performance of Islamic Banks and Conventional Banks operating in Pakistan during the 5 year period of 2015-2019. This study utilizes the CAMEL approach to assess and compare the performance of Islamic Banks and Conventional Banks in Pakistan using a sample of banks. For the purpose of this study, we have used a sample of 4 Conventional banks and 4 Islamic Banks that are operating in Pakistan. All the relevant information for the purpose of comparison for this study was collected from the annual reports of these sample banks which were available on the respective bank's website. The findings of this study indicate that in Pakistan, Islamic banks have performed better in terms of asset quality and earnings than the conventional banks whereas the conventional banks had a better performance in terms of liquidity, management efficiency and capital during the five-year period of consideration. The findings of the analysis also showed that Islamic banks in Pakistan have shown significant growth over the 5 year period 2015-2019.
\end{abstract}

Keywords: Islamic Banks, Conventional Banks, Pakistan, Performance, CAMELS.

\section{INTRODUCTION}

Islamic banking is a banking activity that abides by the Shariah law and operates entirely on the basis of Shariah guidelines and Islamic principles which emphasizes on the ethical and moral values in all dealings of a person. Shariah prohibits Riba (interest) as well as other activities that are contrary to its principles. Islamic banking is different from conventional banking in the sense that its activities are consistent with Shariah principles. Islamic Banking transforms the conventional money lending into tangible asset-based transactions. It focuses on using instruments which are Shariah compliant to generate returns and sharing the risk which may arise in this trading and investments.

Islamic banking which initially started as a niche market for people that were faith sensitive is now an essential part of the global financial system. The history of Islamic banking in Pakistan can be trace back to 1960s when the country witnessed the process of an emergence of Islamic banking. In 1980s these efforts became significant when some significant changes were introduced in the legal framework of Pakistan which included the Banking Companies Ordinance amendment. These steps were taken to convert the banking system of Pakistan to Islamic banking system. However, these efforts could not produce the intended results.

In 2001, the effort to move towards interest free economy and Islamic Banking were relaunched. The State Bank of Pakistan issued a detailed framework for establishment of Islamic Banking with a new approach which has proven to be a success. This approach allowed the 
Islamic Banks in Pakistan to operate with different types of Islamic banking institutions which included Islamic Banks branches of commercial banks, Islamic banks subsidiaries of commercial banks and full-fledged Islamic banks.

In January 2002, Al-Meezan Investments which applied to convert itself into Islamic Bank under the criteria issued by SBP were issued a license to operate as full fledge Islamic Bank in the name of Meezan Bank Limited.

Since then, the Islamic banking industry has been growing consistently in Pakistan. The number of Islamic banks in Pakistan have grown significantly over the last two decades. In September 2020, the Pakistan's banking industry had 22 Islamic banking institutions operating in Pakistan of which 5 institutions are full-fledged Islamic banks and 17 institutions are conventional banks with standalone Islamic banking branches. Similarly, in terms of market share in assets and deposits, the Islamic banking institution stood at $16 \%$ and $17.3 \%$ respectively at the end of September 2020.

This paper attempts to evaluate and compare the performance of Islamic Banks and Conventional Banks operating in Pakistan during the period 2015 to 2019. The analysis will utilize the CAMEL approach indicators to evaluate the performance of both Islamic Banks and Conventional Banks over the 5-year period.

\section{LITERATURE REVIEW}

There have been several studies to compare and evaluate the performance of Islamic banks and Conventional banks in Pakistan as well as around the world using various measures and approaches. This paper contributes to the existing literature on comparative performance of Islamic banking and Conventional banking in Pakistan using the CAMEL approach.

Jafar and Manarvi (2011) carried out their research on Pakistani banks by comparing the performance of Conventional Banks and Islamic banks using the data of 5 conventional banks and 5 Islamic banks over 5 years. Their study showed that Islamic banks performed better in terms of liquidity position and capital adequacy, while the conventional banks performed better in terms of management quality and earnings. In terms of Asset quality both conventional and Islamic banks performance was almost the same.

Another research conducted by Aziz, Husin, and Hashmi (2014) on Islamic and Conventional Banks in Pakistan over the period of 9 years from 2006 to 2014 using the financial ratios concluded that Islamic Banks performed better in terms of asset quality, efficiency, and return, while the conventional banks had comparatively performed better in terms of advances, deposits, capital, and liquidity.

Errol, Baklaci, Aydoğan, and Tunc (2014) compared the performance of Islamic (participation) banks and conventional banks in Turkey during the period 2001 to 2009 using the CAMELS approach and logistic regression method. The findings suggested that Islamic banks in Turkey have a better performance in terms of asset management ratios and earnings while the private banks performed better in terms of sensitivity to market risk measure and capital adequacy ratio.

Akber and Dey (2020) evaluated the performance of Traditional Private Banks and Islamic Banks in Bangladesh through their research using the CAMEL test as the basis of the analysis. The findings of their study indicated that there is no significant difference between Traditional Private banks and Islamic Banks in Bangladesh apart from the quality management. In terms of the management quality and asset quality, the traditional private banks had a better 
performance, while the Islamic banks performed better in terms of capital adequacy and liquidity.

\section{METHODOLOGY}

The performance analysis was conducted using a sample of 4 Islamic banks and 4 Conventional Banks operating in Pakistan. The Islamic Banks selected for this study included Meezan Bank, Dubai Islamic Bank, Bank Islami and Al-Baraka bank. The Conventional banks that were selected for this study are MCB, Habib Bank Limited, United Bank Limited and Bank Alfalah Limited. To compare the performance of Islamic and Conventional Bank in Pakistan we have used the CAMEL approach.

CAMELS Rating system (2020) which was developed in United States in 1979 and is used by banking supervisors to rate the banks on the basis of six important elements of its operation. Initially, this system had five elements, however, in 1995 it was modified to add the sixth element. The six components of CAMELS system are Capital Adequacy, Asset Management, Management Efficiency, Earnings, Liquidity and Sensitivity.

Table 1. The CAMEL elements and measurement ratios

\begin{tabular}{|l|l|}
\hline Elements & Measurement Ratio \\
\hline Capital Adequacy & Capital Adequacy Ratio \\
\hline Asset Quality & Non-performing Loans/Total Advances \\
\hline Management Efficiency & Efficiency Ratio (Operating Expense/Revenue) \\
\hline Earnings & Return on Equity, Return on Assets \\
\hline Liquidity & Advances/Deposits \\
\hline
\end{tabular}

The sample period for this study includes a 5-year period from 2015 to 2019. All the financial data for the comparative analysis was extracted from the Annual Reports of the sample banks included in our study which was available on the respective bank's website. For the purpose of comparison in performance of Islamic and Conventional Banks we have calculated the average for each ratio for each year considered for the study.

\section{Capital Adequacy Ratio}

\section{FINDINGS}

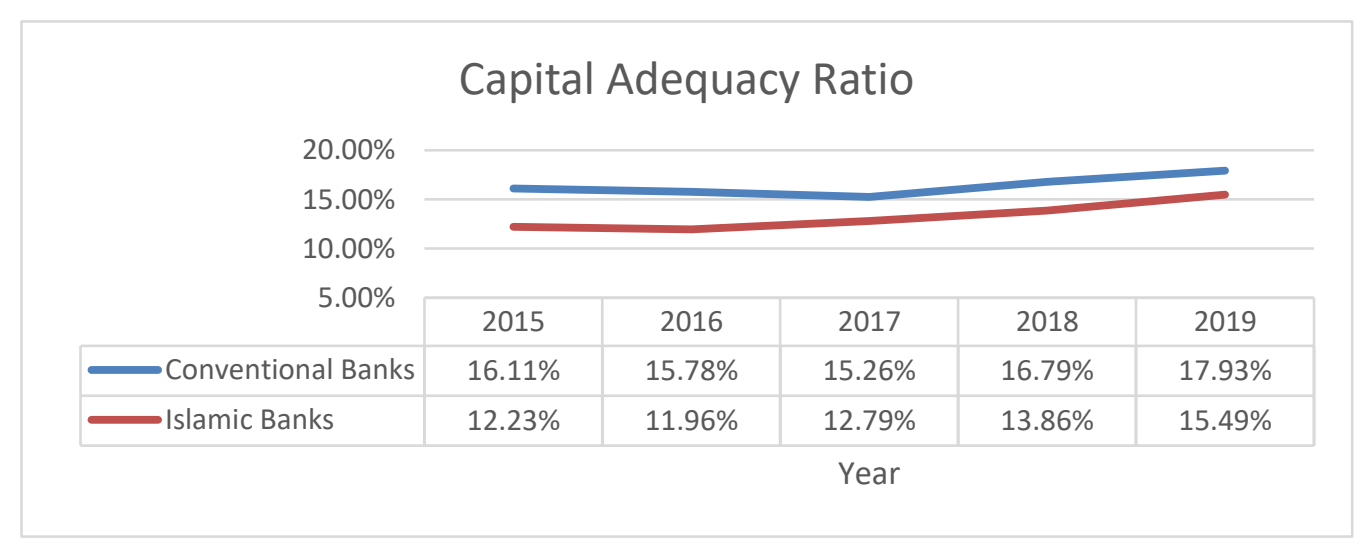

Figure 1. Capital Adequacy Ratio 
Capital Adequacy ratio measures financial institution's strength to absorb potential losses before there is a risk of the institution becoming insolvent. It is computed as the ratio of capital to risk weighted assets. Before 2019, the Capital Adequacy ratio was set at $10.25 \%$ and it was gradually increase to $12.5 \%$ by $31^{\text {st }}$ December 2019 as per the Basel III requirement.

According to the graph above the capital adequacy ratio for both Islamic banks and conventional banks is above the minimum requirement of Basel III. The Islamic Banks CAR ratio has increased over the years significantly relative to the conventional bank's capital adequacy ratio over the 5-year period by around 26\%. Conventional Banks CAR saw a slight decline during the period 2015-2017 but then increase by around 18\% during the period 20172019. However, over the period of study, the Conventional Bank's Capital Adequacy ratio has been above its conventional counterpart.

\section{Asset Quality}

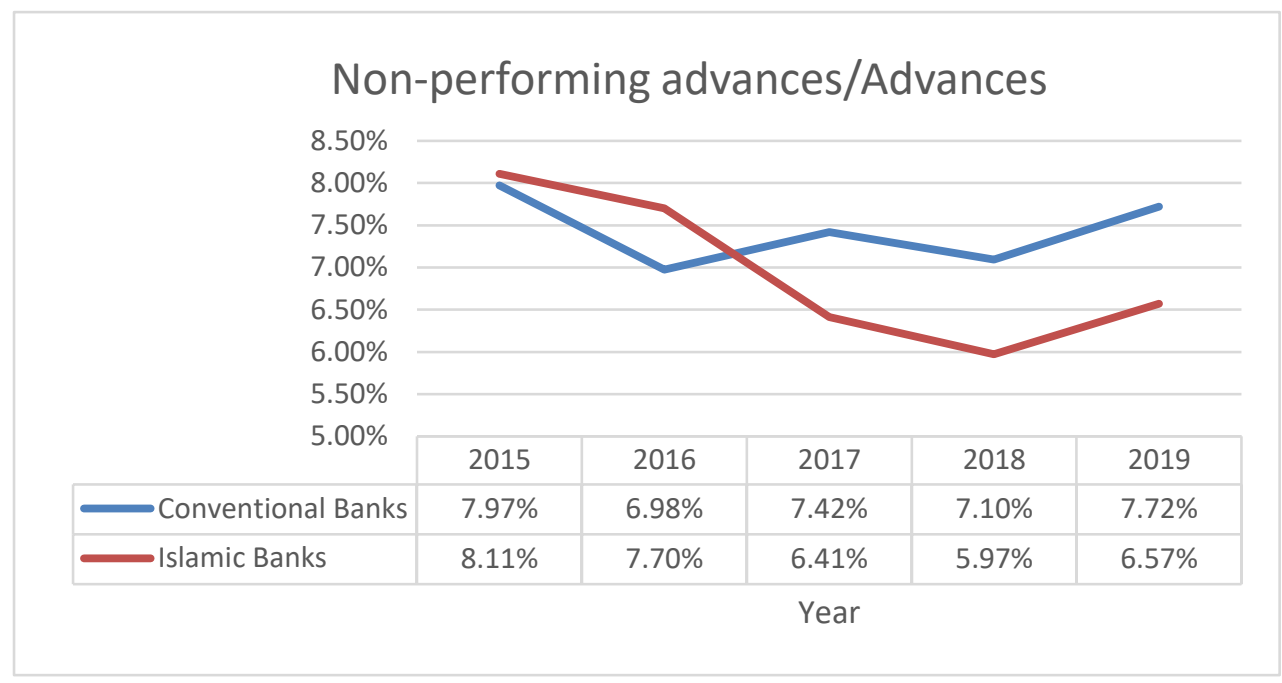

Figure 2. Non-performing advances/Advances

The paper evaluates the Asset Quality of the banks by comparing Non-performing advances to Advances. This ratio measures the proportion of the loans which are not being efficiently recovered.

The above graph shows that during the period 2015-2018, the Islamic Banks NPL to advances ratio showed improvement while the conventional banks NPL to advances ratio displayed a meager fluctuation over the 5-year period with a slight decline during 2016 and increase in 2017. During the period 2017 to 2019 both Islamic banks and conventional banks followed the same trend in NPL to advances ratio. However, over the period of study, the NPL to advances ratio of Islamic banks decreased by around $20 \%$ depicting a positive trend in asset quality. Hence, in terms of asset quality, the Islamic banks performance was better than its conventional counterpart over the 5-year period. 


\section{Management Efficiency}

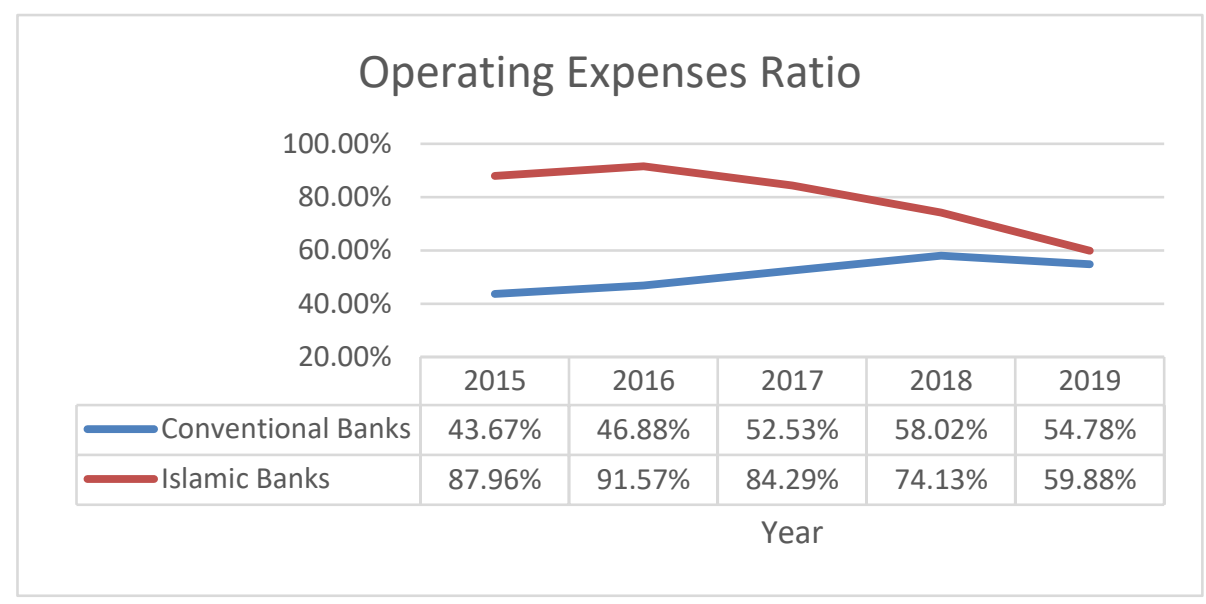

Figure 3. Operating Expenses Ratio

The paper evaluates the Management efficiency of Islamic and Conventional Banks using the Operational expenses to revenue ratio which measures the bank's efficiency. It shows how well the bank is able to control its overhead expenses.

According to the graph above, during the period of study, Islamic banks had significantly improved their efficiency ratio by around $32 \%$. Since the Islamic banking industry is a growing industry, this ratio shows that they have been working on improving the efficiency over the years which is evident from the performance over the 5-year period. On the contrary, the conventional banks efficiency ratio displayed an increasing trend during 2015-2018 while it fell in the year 2019. However, overall, the conventional banks had a comparatively lower operating expense to revenue ratio during the 5-year period.

\section{Earnings}

The paper evaluates the Earnings element of the CAMEL analysis using the Return on Equity and Return on Assets Ratio.

\section{Return on Equity}

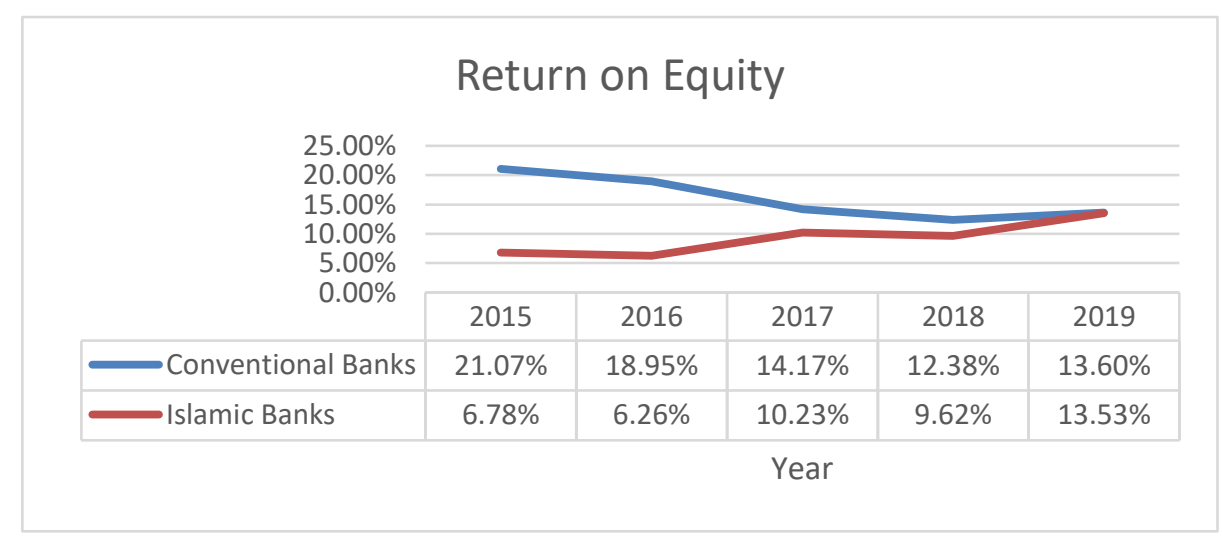

Figure 4. Return on Equity 
The Return on Equity is a measure of profitability of a company in relation to its equity. It is useful for measuring the how efficiently a company is able to generate profit from the investment of shareholders.

During the period of study, the Islamic banks Return on Equity has increased significantly by around $100 \%$ while on the other hand conventional banks have displayed a declining return on equity over the same period by around by around 35\%. Overall, Islamic banks have performed significantly better than Conventional banks in terms of Return on Equity measure.

\section{Return on Assets}

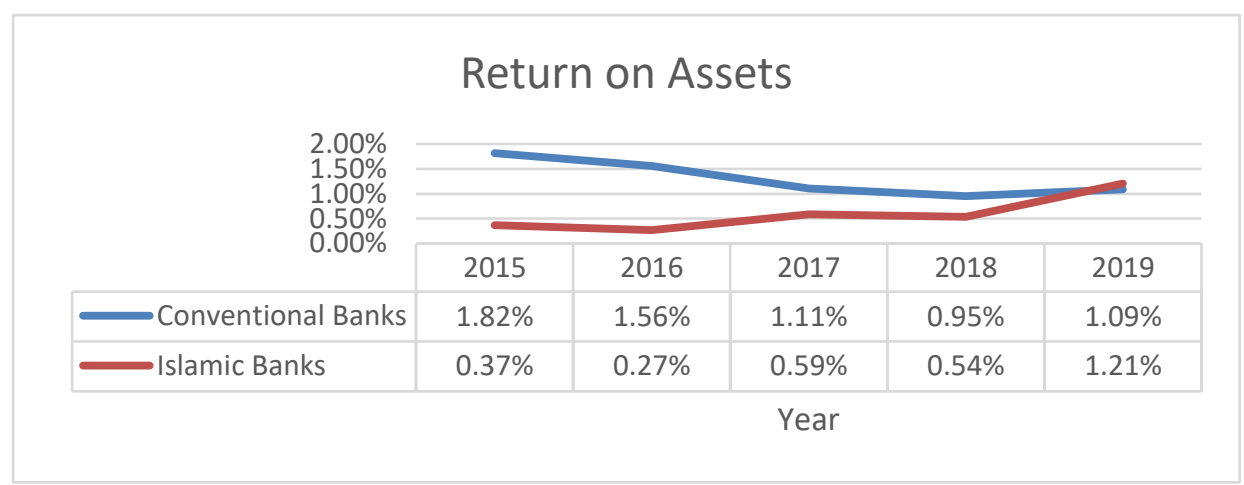

Figure 5. Return on Assets

The Return on Asset is a measure of how efficient the management of the bank is in generating the earnings from its assets. It is a useful measure for showing how profitability a company utilizes its assets.

Islamic banks have shown an increasing trend on Return on Asset over the 5-year period while the conventional banks have shown a declining ROA trend over the period 2015 to 2018 with a slight increase in ROA in 2019. Overall, there have been a very insignificant change in the Return on Asset over the 5-year period for both Islamic and Conventional Banks. However, we can infer from the data and the graph above that the Islamic banks have performed better than the conventional banks in terms of ROA.

\section{Liquidity}

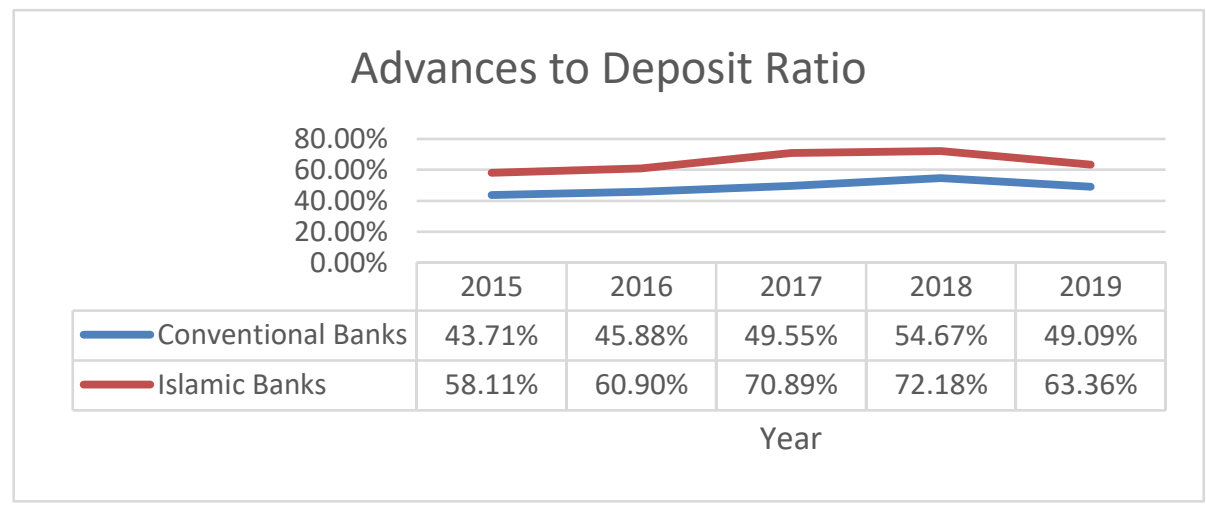

Figure 6. Advances to Deposit Ratio 
The advances to deposit ratio (ADR) measures the bank's liquidity condition by comparing the bank's total advances to its total deposits. It shows if the bank is funding all of its advances from its deposits or is it relying on borrowing from other banks or funding from capital market.

The Advances to Deposit ratio for both conventional and Islamic bank showed an increasing trend during the period 2015-2018 and declined during the period 2018-2019. However, the Islamic banks showed a significant increase in ADR during the 4-year period. The conventional banks on the other hand had a relatively stable advance to deposit ratio over the 5year period.

\section{CONCLUSION}

Over the last two decades Islamic Banking in Pakistan has grown significantly which is evident from the number of Islamic banks operating in Pakistan that have increased over the years, Islamic banking sector's assets and deposit share and its financial performance over the years. This paper analyzed the performance of Islamic and Conventional Banks in Pakistan using the CAMEL approach during the period between 2015 to 2019. The result of the analysis showed that Islamic banks over the period 2015-2019 has shown significant growth. It has been able to control its operating expense to revenue ratio and non-performing loans to advances ratio. Also, it has shown growth in terms of Return to Equity, Return to Asset and Capital Adequacy ratio over the 5-year period.

However, if we compare the performance of Islamic banks with Conventional banks the analysis shows that in terms of Asset Quality and Earnings, Islamic Banks performed better than conventional banks. The Conventional Banks on the other hand, had better performance in terms of management efficiency, liquidity, and capital adequacy.

\section{REFERENCES}

Akber, S. M., \& Dey, A. (2020). Evaluation of the Financial Performance between Traditional Private Commercial Banks and Islamic Banks in Bangladesh. International Journal of Islamic Banking and Finance Research, 4(2), 1-10.

Aziz, S., Husin, M., \& Hashmi, S. H. (2016). Performance of Islamic and conventional banks in Pakistan: A comparative study. International Journal of Economics and Financial Issues, 6(4).

Beers, B. (2020, September 16). What does a high capital adequacy ratio indicate? Retrieved from https://www.investopedia.com/ask/answers/040115/what-does-it-mean-whencompany-has-high-capital-adequacy-ratio.asp

CAMELS Rating System. (2020, December 24). Retrieved from https://en.wikipedia.org/wiki/CAMELS_rating_system

Erol, C., Baklaci, H. F., Aydoğan, B., \& Tunç, G. (2014). Performance comparison of Islamic (participation) banks and commercial banks in Turkish banking sector. EuroMed Journal of Business. 
Islamic banking. (n.d.). Retrieved from https://www.islamic banking.com/explore/islamicfinance/islamic-banking

Islamic Banking $\quad$ Bulletin. $\quad$ (n.d.). $\quad$ Retrieved from https://www.sbp.org.pk/ibd/Bulletin/2020/Sep.pdf

Jaffar, M., \& Manarvi, I. (2011). Performance comparison of Islamic and Conventional banks in Pakistan. Global journal of management and business research, 11(1).

Kagan, J. (2020, August 29). Learn about the camels rating system. Retrieved from https://www.investopedia.com/terms/c/camelrating.asp\#: :text=CAMELS\%20is\%20an\%2 0international\%20rating, \%2C\%20Liquidity\%2C\%20and\%20Sensitivity.\%22

State bank of Pakistan. (n.d.). Retrieved from https://www.sbp.org.pk/BS/RCSP.asp

State bank of Pakistan. (n.d.). Retrieved from https://www.sbp.org.pk/IB/about.asp

State bank of Pakistan. (n.d.). Retrieved from https://www.sbp.org.pk/70/sup-5.asp

\section{Copyrights}

Copyright for this article is retained by the author(s), with first publication rights granted to the journal. This is an open-access article distributed under the terms and conditions of the Creative Commons Attribution license (http://creativecommons.org/licenses/by/4.0/) 